\title{
Prasa polska o wyborach do Parlamentu Europejskiego w Polsce i w Niemczech w 2014 roku
}

Streszczenie: Zasadniczym celem artykułu jest przedstawienie opinii publicystów prasy polskiej na temat wyników wyborów do Parlamentu Europejskiego przeprowadzonych w Polsce i w Niemczech w 2014 roku. W publikacji zwrócono uwagę na metody prowadzenia kampanii przez polskie i niemieckie ugrupowania polityczne oraz punkty ciężkości w programach wyborczych partii w obu krajach. Przedstawiono również głównych zwycięzców i przegranych Eurowyborów z 2014 roku.

Słowa kluczowe: integracja europejska, Parlament Europejski, eurosceptycyzm, Eurowybory, kampania wyborcza, prasa polska

W maju 2014 roku w Polsce i w Niemczech, podobnie jak w pozostałych państwach członkowskich UE odbyły się wybory do Parlamentu Europejskiego (PE). Choć w Warszawie i Berlinie nie wiązano z nimi takich nadziei jak z wyborami krajowymi to ich wynik miał dać odpowiedź na kilka istotnych pytań dotyczących przyszłości Europarlamentu VIII kadencji. Pierwsze pytanie dotyczyło kierunku zmian wyznaczonego przez główny trend obecny w Parlamencie Europejskim po poprzednich Eurowyborach z 2009 roku, który reprezentowany był przez największe proeuropejskie frakcje w PE: Europejską Partię Socjalistów oraz Postępowy Sojusz Socjalistów i Demokratów. Dotyczył on m.in. ratowania zadłużonej strefy euro, pomocy uchodźcom i emigrantom napływającym do Europy z Afryki Północnej i Bliskiego Wschodu. Drugie pytanie dotyczyło obecności w Parlamencie Europejskim partii eurosceptycznych. To one, po Eurowyborach z 2009 roku rosły coraz bardziej w siłę i wyrażały niechęć społeczeństw UE wobec tzw. „obcych”. Akcentowały również rozczarowanie Europejczyków działaniami instytucji Unii Europejskiej. W przypadku krajowej sceny politycznej wyniki wyborów do Parlamentu Europejskiego miały wskazać, które partie w Polsce i w Niemczech przejmą inicjatywę polityczną w kampanii do kolejnych wyborów krajowych. 


\section{Eurowybory w Polsce w 2014}

25 maja 2014 roku w Polsce odbyły się wybory do Parlamentu Europejskiego. W tej kadencji Europarlamentu wybrano 51 eurodeputowanych z Polski na kolejną, pięcioletnią kadencję. Przy frekwencji sięgającej 23,84\% osób zwyciężyła Platforma Obywatelska, która otrzymała 32,13\% głosów. Kolejne miejsca zajęły: Prawo i Sprawiedliwość 31,78\% głosów, Sojusz Lewicy Demokratycznej 9,44\% głosów, Nowa Prawica 7,15\% głosów, Polskie Stronnictwo Ludowe 6,80\% głosów. Pięciokrotnego progu wyborczego nie przekroczyły partie: Solidarna Polska, koalicja EuropaPlus-Twój Ruch, Polska Razem, Ruch Narodowy, Partia Zieloni, Komitet Wyborczy Demokracja Bezpośrednia.

Kampania wyborcza do Europarlamentu rozpoczęła się na początku kwietnia 2014 roku. Początkowo w mediach pojawiło się niewiele informacji na temat kandydatów na eurodeputowanych. W miarę zbliżania się terminu głosowania coraz częściej komentowano głównie strategie wyborcze komitetów partii oraz język jakim posługiwano się w eurokampanii. Przedstawiono również sylwetki kandydatów - „stare” twarze kampanii wyborczej oraz „nowe”, którymi okazała się liczna grupa celebrytów, rywalizująca o stanowiska w Strasburgu.

W tym czasie w tygodniku „Wprost” pojawił się interesujący artykuł ukazujący nowe twarze kampanii, które partie wystawiły na listach do walki o miejsca w Europarlamencie. Katarzyna Nowicka na łamach artykułu Pudelek Europejski przedstawiła znane i obecne w mediach postacicelebrytów, które w tych wyborach miały być lokomotywą wizerunkową partii politycznych i przyciagnąc do urn wyborczych, niechętnych do uczestnictwa, właśnie w wyborach europejskich. I choć zdaniem autorki nie mieli oni większych szans na zdobycie miejsc premiowanych w Europarlamencie wykonywali ważne zadania dla swoich partii: „mają odegrać role Zająców, które napędzają ludzi do urn” (Nowicka, 2014). Do najważniejszych twarzy kampanii publicystka tygodnika zaliczyła: prezes Warty Poznań Izabelę Łukomską-Pyżalską, siatkarza Michała Bąkiewicza, aktorkę Weronikę Marczuk, pływaczkę Otylię Jędrzejczak, piłkarza Macieja Żurawskiego, trenera piłki ręcznej Bogdana Wentę oraz boksera Tomasza Adamka.

Podobne zagadnienie poruszył Piotr Gursztyn na łamach tygodnika „Do Rzeczy”. W artykule zatytułowanym Dziwni kandydaci wskazał on na zależność pomiędzy pozycją partii na arenie politycznej Polski a koniecznością pozyskania przez dane ugrupowanie - celebryty, osoby wy- 
stawianej na listach partii w Eurowyborach. Zauważył, ,że im partia jest bardziej zdesperowana, tym chętniej wystawia celebrytów" (Gursztyn, 2014a). W dalszej części artykułu podkreślił, że głos, wzrost, aparycja to kryteria, którymi mogą kierować się wyborcy, stawiając na kandydatów do foteli w Strasburgu. Zauważył, że w wyborach takich jak europejskie merytoryczne kryteria nie odgrywają wiodącej roli, a niska frekwencja wyborcza to potwierdza (Gursztyn, 2014a).

Istotnym zagadnieniem poruszanym w kampanii wyborczej przez partie polityczne w Polsce był również tzw. kryzys ukraiński.

Wspomniany już publicysta Piotr Gursztyn na łamach tygodnika „Do Rzeczy" zasugerował wpływ tzw. zagadnienia ukraińskiego na preferencje wyborcze elektoratu w Polsce. W artykule zatytułowanym Polski euromajdan zwrócił uwagę, że sztabowcy partii politycznych zastanawiają się jak wykorzystać strach przed Władimirem Putinem i Rosją do kampanii wyborczej. Ocenił, że to bezprecedensowe zjawisko nie będzie miało wpływu na polskie Eaurowybory: „dopóty, dopóki Putin nie puści ze smyczy swoich czołgów” (Gursztyn 2014b).

Z kolei publicyści tygodnika „W Sieci” Anna Wojciechowska oraz Piotr Zaremba na łamach artykułu Kampania psiego swędu zwrócili uwagę na marketingową sztuczkę Platformy Obywatelskiej polegającą na konsolidacji głosów elektoratu wokół Donalda Tuska, w obliczu strachu wobec aneksji Krymu przez Rosję. Nawiązali oni tym samym do wypowiedzi premiera Polski o tym, że stawką wyborów europejskich jest to czy dzieci we wrześniu pójdą do szkoły (Wojciechowska, Zaremba, 2014).

14 maja na łamach „Gazety Wyborczej” zwrócono uwagę, że z okazji zbliżającej się rocznicy bitwy pod Monte Casino Donald Tusk nie tylko weźmie udział w obchodach 70-lecia bitwy, ale spotka się również z papieżem Franciszkiem. Publicystka dziennika Renata Grochal podkreśliła, że jest to nieprzypadkowy socjotechniczny zabieg. „PO dąży w ten sposób do otrzymania poparcia ze strony niezdecydowanego elektoratu - osób powyżej 55 lat. To ludzie, którzy pamiętają wojnę, boją się kryzysu za wschodnią granica, przywiązują uwagę do rocznic historycznych i są mocno związani z kościołem katolickim" (Grochal, 2014), argumentowali członkowie sztabu wyborczego PO. Zdaniem publicystki „Gazety” sprzyjającą okolicznością dla PO było również nagłaśnianie w mediach właśnie sprawy ukraińskiej oraz rocznicy 10-lecia członkostwa Polski w Unii Europejskiej.

Wagę zagadnień wschodnich w polityce unijnej na najbliższe lata podniósł również Konrad Szymański, późniejszy minister w rządzie PiS ds. 
europejskich na łamach kwartalnika „Rzeczy Wspólne”. W artykule zatytułowanym Parlament Europejski? wskazał on sześć obszarów unijnych, które jego zdaniem miały wyznaczyć polityczny kierunek działalności Parlamentu Europejskiego na najbliższe lata i były kluczowe z polskiego punktu widzenia. Wśród najważniejszych wymienił najbardziej nieprzewidywalny jego zdaniem kierunek Unii Europejskiej, jakim był Wschód i problemy jakie wiązały się z rozwojem sytuacji na Ukrainie (Szymański, 2014).

Przez cały okres kampanii wyborczej do PE publicyści prasy polskiej zwracali uwagę na brak zainteresowania Polaków wyborami europejskimi. Na miesiąc przed wyborami przestrzegała przed tym „Rzeczpospolita”. Zdaniem publicystów dziennika wynikało to z niewiedzy elektoratu oraz słabego zaangażowania polityków w kampanię wyborczą.

Paweł Majewski na łamach artykułu Wyborcy nie widza kampanii zwrócił uwagę, iż nowoczesne techniki oddziaływania na elektorat nie zdają egzaminu. Spoty internetowe zamieszczane w sieci prawie w ogóle nie docierają do wyborców, i dlatego nie mogą być źródłem informacji o poglądach partii i kandydatów. Powołał się na wypowiedź specjalistki od analizy polityki w nowych mediach Marii Nowiny-Konopki, która oceniła, że ludzie ,,przesyłają sobie spoty, ale w ramach żartu, a nie kampanii wyborczej" (Majewski, 2014). Zauważyła ona także, że politycy nie potrafili wykorzystać np. internetu, ,te filmy wyglądają jak te z mediów tradycyjnych. Nie pozwalają na interaktywność" (Majewski, 2014) - zasugerowała. Wśród najczęściej oglądanych przez społeczeństwo prześmiewczych clipach publicysta „Rzeczpospolitej” wymienił spot posłanki EPTR Anny Kubicy, która naśladowała dziennikarkę Annę Jaworowicz, kandydata EPTR Ryszarda Kalisza, który odejmując $100 \mathrm{~cm}$ od swojego pasa liczył głosy poparcia czy też Anny Słomkowskiej również kandydatki EPTR, która w ostrym języku zignorowała „temat” Krymu. Zdaniem Majewskiego, kampania w sieci ma bardzo ograniczony zasięg oddziaływania, a elektorat ciągle przyzwyczajony jest do tradycyjnego, telewizyjnego przekazu informacji o kampanii wyborczej i poglądach kandydatów.

Z kolei 19 maja na łamach popularnej „Gazety” brukselski korespondent Tomasz Bielecki w artykule zatytułowanym Po co nam Parlament Europejski? starał się zmobilizować elektorat do uczestnictwa w majowych wyborach do Parlamentu Europejskiego. Publicysta świadomy nikłego zainteresowania Polaków wyborami europejskimi wymienił najistotniejsze zadania realizowane przez Europarlament (m.in. współdecydowanie 
o kosztownej polityce rolnej, energetycznej, funduszach unijnych, polityce budżetowej) oraz wskazał liczne zasługi eurodeputowanych, które w miarę wzrostu kompetencji Parlamentu Europejskiego powinny być dla społeczeństwa europejskiego coraz bardziej zauważalne. Wśród najważniejszych zadań wymienił: zbijanie cen roamingu, a w przyszłości całkowite skasowanie opłat za roaming, ograniczenie emisji $\mathrm{CO}_{2}$ do atmosfery, zwalczanie projektu zakazu produkcji papierosów mentolowych i slimów, zabezpieczenie Europy przed szpiegostwem ze strony USA oraz odrzucenie forsowanej przez USA umowy ACTA z 2012 roku (Bielecki, 2014). Publicysta „Gazety Wyborczej” powołał się na słowa Agnieszki Łady - eksperta Instytutu Spraw Publicznych, która zasugerowała, że „frekwencja w eurowyborach wpływa na prestiż krajów Unii. Gdyby obywatele Polski pokazali w eurowyborach, że chcą współdecydować o losach Unii i im na niej zależy to wzmocniłoby niewątpliwie autorytet Polski w dyskusjach o przyszłości Unii” (Bielecki, 2014).

W polskiej publicystyce szeroko komentowano również rosnące poparcie Polaków dla eurosceptycznej partii Janusza Korwin-Mikke - Nowa Prawica.

Tomasz Sommer na łamach „Najwyższego Czasu” - organu prasowego partii zapowiadał przekroczenie progu wyborczego przez to ugrupowanie, a więc w jego rozumieniu - zwycięstwo Nowej Prawicy w Eurowyborach 2014. Autor artykułu Scenariusz powyborczy A.D. 2014 zwrócił też uwagę, że Janusz Korwin-Mikke w niedługiej przyszłości stanie się gwiazdą nowego Europarlamentu, a przy nim zarówno Nigel Farage, jak i Godfrey Bloom „bladzi jak prześcieradło” (Sommer, 2014). W dalszej części artykułu uzasadniał, że o sukcesie Nowej Prawicy zadecydują: efekt świeżości oraz stała obecność w mediach bez odpowiedzialności za polityczne decyzje.

Do wzrastającego sondażowo poparcia dla partii Korwina-Mikke odniosła się również Kamila Baranowska na łamach tygodnika „Do Rzeczy". W artykule zatytułowanym Choroba wieku młodzieńczego zwróciła uwagę na grupy młodych osób wspierających eurosceptyczną partię J. Korwin-Mikkego, osoby które - jej zdaniem - mogłyby być środowiskiem prężnym, lobbującym na temat nowych, liberalnych rozwiązań, ale nie są, gdyż nie traktuje się ich poważnie. Zdaniem autorki czarno-biała rzeczywistość, jaką przedstawia im partia Korwina-Mikke oraz hasła takie jak: wprowadzenie w Polsce kary śmierci, obniżenie podatków, zmniejszenie grupy urzędników czy prywatyzacji, mogą przekonywać ,ale tylko tych którzy kierują się sercem, a nie rozumem” 
(Baranowska, 2014). Autorka nazwała młodych popleczników J. Korwin-Mikke - sezonowymi.

Im bliżej było do ogłoszenia wyników Eurowyborów, tym częściej sukces wyborczy partii Janusza Korwina-Mikke polegający na przekroczeniu 5\% progu wyborczego zapowiadały czołowe periodyki prasowe w Polsce. Redaktora Naczelnego Instytutu Idei oraz Szefa Instytutu Obywatelskiego nie dziwiła ta sytuacja. Jarosław Makowski na łamach artykułu Fruwajacy elektorat buntu zauważył, że w Polsce już od kilku lat mamy do czynienia z elektoratem krzywdy i protestu, który w obecnych eurowyborach wskazał już swojego lidera, którym jest Janusz Korwina-Mikke: „Jest to 6-8\% grupa wyborców, ludzi, którzy aktywizują się w okolicach każdych wyborów. Za każdym razem znajdują sobie inne źródło mobilizacji, innego lidera $\mathrm{i}$ inne powody protestu i krzywdy. To grupa na tyle silna by wprowadzić marginalną partię do głównego nurtu polityki. I na tyle słaba, że nie może realnie wywrócić politycznego ładu do góry nogami” (Makowski, 2014).

Podczas trwającej kampanii wyborczej do Europarlamentu w prasie polskiej pojawiły się także artykuły odnoszące się do kwalifikacji kandydatów do foteli w Strasburgu i ich zaangażowania w prace Europarlamentu.

Na 3 dni przed Eurowyborami na łamach „Gazety Wyborczej” pojawił się Euroranking - w którym publicyści popularnego dziennika przedstawili sylwetki pięciu najlepszych oraz pięciu najgorszych polskich eurodeputowanych poprzedniej kadencji. Za główne kryteria oceny przyjęli: statystyki z ich wystapień, sprawozdań, poprawek, interpelacji, a także ich kontakty z innymi europosłami. W ocenie dziennika w latach 2009-2014 Polskę najlepiej reprezentowali: Danuta Hübner (m.in. za przewodzenie komisji rozwoju regionalnego oraz przestrzeganie korzystnych dla Polski przepisów dotyczących polityki spójności), Jacek Saryusz-Wolski (m.in. za zaangażowanie w sprawy ukraińskie i stworzenie Zgromadzenia Parlamentarnego Partnerstwa Wschodniego), Jerzy Buzek (m.in. za wysokie notowania jako sprawnego unijnego urzędnika oraz w pewnym stopniu za przewodzenie Parlamentowi Europejskiemu), Jan Olbrycht (m.in. za wkład w politykę spójności oraz fundusze regionalne), Wojciech Olejniczak (m.in. za zaangażowanie w działalność komisji rozwoju regionalnego, także rolnictwa i rozwoju wsi), Róża Thun (za działalność w komisji rynku wewnętrznego i ochrony konsumentów) (Bielecki, Grochal, Kondzińska, 2014).

Za zmarnowaną uznano kadencję posłów tzw. Ziobrystów: Zbigniewa Ziobry, Jacka Kurskiego oraz Tadeusza Cymańskiego (m.in. 
za sojusz z frakcją NFD, której lideruje Partia Niepodległości Zjednoczonego Królestwa - populistyczna, antyimigracyjna, ksenofobiczna i w pewnym sensie antypolska, której przewodzi Nigel Farage). Zdaniem publicystów „Gazety Wyborczej” 5 lat w Europarlamencie zmarnował także Marek Migalski z Polski Razem, który wydał książkę Parlament antyeuropejski. Opisał w niej system legalnej korupcji w UE, a której sam był częścią i pobierał olbrzymie dochody (Ibidem).

Po 25 maja 2014 roku w publicystyce polskiej pojawiło się wiele interesujących artykułów traktujących o polskich Eurowyborach. Publicyści polscy oceniali strategie wyborcze partii politycznych, zaangażowanie polityków w Eurowybory oraz zwracali uwagę na zwycięzców i przegranych wyborów do PE.

Wojciech Wybranowski w artykule Od czarnej teczki do dziadka z Wermachtu, na łamach „Do Rzeczy” ocenił taktykę i technikę kampanii do Europarlamentu i podkreślił, że pomimo kilku nieznaczących jego zdaniem incydentów kampania przebiegała spokojnie. Jego zdaniem dla głównych ugrupowań politycznych w Polsce eurowyścig był tylko „walką o polityczne pole position przed przyszłorocznymi wyborami parlamentarnymi” (Wybranowski, 2014).

Zbigniew Lipiński na łamach „Myśli Polskiej” w artykule Korwin Góra, Palikot na dnie!, zaznaczył, że Eurowybory były wyjątkowo nieciekawe, ale ich wynik wzbudził nie lada emocje. Podkreślił, że rezultat osiągnięty przez przeciwników UE - z Januszem Korwin-Mikke na czele - rozbudza ostrożną nadzieję, ,że Polska odzyska jednak niepodległość" (Lipiński, 2014). Porównał wynik uzyskany przez eurosceptyków Janusza Korwin-Mikke w Polsce z wynikiem osiagniętym przez Marine Le Pen we Francji oraz Nigela Farag'ea w Wielkiej Brytanii. Uznał, że polski rezultat „wprawdzie to pyłek, ale może on w przyszłości przerodzić się w antyunijną kurzawę" (Lipiński, 2014).

Grzegorz Rzeczkowski na łamach tygodnika „Polityka” w artykule zatytułowanym Korwiniada korygował te opinie. Zauważył on, że mocną stroną kampanii prowadzonej przez Janusza Korwin-Mikke była jego wieloletnia obecność w polityce, duża aktywność jako blogera w internecie, stabilne, wygłaszane od ponad 20 lat poglądy konserwatywno-liberalne. Jego zdaniem taka bezceremonialność przyciagnęła młody elektorat, który tym razem nie dla Janusza Palikota ale dla Korwina-Mikke był łaskawy. Publicysta „Polityki” przestrzegał jednak, że łaska szczególnie młodych wyborców jest chwiejna: ,jeśli w ich oczach Korwin przekro- 
czy cienką linię śmieszności, w swoim ekscentryzmie przesadzi, fortuna może nagle się odwrócić” (Rzeczkowski, 2014).

Ciekawa ocenę Eurowyborów w Polsce zawarł Jarosław Flis na łamach „Rzeczy Wspólnych”. Krakowski socjolog zwrócił uwagę, że zwycięstwo PO w wyborach europejskich może oznaczać pułapkę bierności. W rozmowie z Bartoszem Marczukiem podkreślił, że „PO straciła przewagę, jaką miała, ale ocaliła dobre samopoczucie. A to dla niej najgroźniejsza mieszanka... Z werdyktu wyborców PO może wysnuć wniosek: jesteśmy słabsi, ale starać to się jakoś specjalnie nie musimy" (Marczuk, 2014). Wynik osiagnięty przez Janusza Palikota skomentował jednoznacznie: „...jest już passe. Wykonał już tyle manewrów, spalił już tyle mostów, że trudno będzie wyobrazić sobie jego powrót" (Marczuk, 2014).

Z kolei publicysta tygodnika „W Sieci” - Wiktor Świetlik na łamach artykułu Eurozachwyty Świetlika przedstawił - jego zdaniem - zestawienie najlepszych akcji, najlepszych zawodników tzw. Eurowyborów. Wśród najważniejszych wymienił m.in. Janusza Korwin-Mikke - „,. im większą głupotę powiedział, tym bardziej go pompowano”, Krystynę Pawłowicz - „...jej temperament okazał się skuteczniejszy w szkodzeniu PiS niż tabun agentów specjalnych”, Tomasza Adamka - „,...miał bronić w Eurparlamencie wartości, bo żona mu kazała, ....a jedyną wartością jaką mógłby bronić jest wartościowa dieta" (Świetlik, 2014).

Wynik wyborczy osiagnięty przez dwa najsilniejsze ugrupowania polityczne w Polsce oceniła z kolei Joanna Lichocka na łamach „Gazety Polskiej”. W artykule zatytułowanym Ostatni taki wynik PO postawiła tezę, że Eurowybory w Polsce zakończyły się faktycznym remisem, gdyż Platforma Obywatelska zwyciężyła przewagą 24 tysięcy głosów elektoratu nad Prawem i Sprawiedliwością. Na łamach artykułu zasugerowała, że przy tak niskiej frekwencji wyborczej w następnych wyborach, krajowych partię Donalda Tuska może czekać klęska. Dla publicystki tygodnika rzeczywistym zwycięzcą wyborów europejskich został PiS i był to najlepszy wynik, jaki osiagnęła partia Jarosława Kaczyńskiego w Eurowyborach. Przekładając wyniki do polskiej rzeczywistości zasugerowała, że ,jeśli nic gwałtownego się nie wydarzy a PiS nie popełni poważnych błędów to w wyborach krajowych, najpierw samorządowych, a potem parlamentarnych powinien wygrać i to zdecydowanie" (Lichocka, 2014).

W prasie polskiej sugerowano, że podczas kampanii do PE w 2014 roku (podobnie jak podczas Eurowyborów w 2004 roku, jak i w 2009 roku) zauważalny był brak pełnego zaangażowania polityków w Eurowybory. Dlatego też kampanię oceniono jako ospałą i niemrawą. Strategia 
polityków w kampanii wyborczej polegała raczej na przypomnieniu się elektoratowi, przy relatywnie niskim nakładzie sił i środków. Dlatego też w publicystyce często sugerowano, że Eurowybory stanowiły rozgrzewkę przed wyborami parlamentarnymi i samorządowymi, i były sprawdzianem przed walką o głosy wyborcze na polskiej scenie politycznej. W prasie polskiej zwrócono uwagę na niewielką przewagę PO nad PiS-em i zasugerowano, że właściwie to Eurowybory zakończyły się remisem między tymi partiami. Część z nich zapowiadało nawet porażkę partii Donalda Tuska w kolejnej potyczce wyborczej z partią Jarosława Kaczyńskiego. W prasie polskiej wyróżniono innego zwycięzcę Eurowyborów 2014. Był nim Janusz Korwin-Mikke, którego ugrupowanie - Nowa Prawica uzyskało 7,15\% głosów.

\section{Eurowybory w Niemczech w 2014 roku}

25 maja 2014 roku w Niemczech po raz kolejny odbyły się wybory do Parlamentu Europejskiego. W odróżnieniu od Eurowyborów sprzed pięciu lat, te z 2014 roku nie stanowiły preludium do wyborów krajowych, ale były pierwszą poważną próbą sił po jesiennych wyborach do Bundestagu z 2013 roku. Kampania wyborcza do Europarlamentu w Niemczech rozpoczęła się po zgłoszeniu list wyborczych w marcu 2014 roku i od samego początku raczej nie miała konfrontacyjnego charakteru. $\mathrm{Z}$ uwagi na zawarte porozumienia pomiędzy koalicjantami CDU-CSU-SPD, liderzy tych ugrupowań starali się unikać sporów w trakcie trwającej kampanii wyborczej. Nie oznacza to jednak, że jedności koalicji nie zakłócały mniejsze lub większe incydenty. Jak zauważa Piotr Kubiak, analityk z poznańskiego Instytutu Zachodniego dotyczyły one głównie polityki imigracyjnej i kwestii ukraińskiej (Kubiak, 2014, s. 309).

W maju 2014 roku Markus Farber - jeden z liderów CSU i jednocześnie kandydat do Parlamentu Europejskiego zaatakował główną twarz kampanii SPD, przewodniczącego Parlamentu Europejskiego, Martina Schulza, za słowa które wypowiedział po tragedii, która miała miejsce koło Lampedusy w 2013 roku. Lider SPD zapowiedział, że „każdy Afrykanin, który osiągnie ziemię europejską powinien być serdecznie witany w Unii Europejskiej" (Kubiak, 2014, s. 309). Za nieroztropne słowa Martin Schulz został nazwany przez Farbera kierownikiem bandy przemytników.

Istotnym tematem poruszanym w kampanii wyborczej do Europarlamentu w Niemczech był również tzw. problem ukraiński. Dzielił on nie 
tylko polityków niemieckiej sceny politycznej, ale również społeczeństwo. W obliczu kryzysu politycznego na Ukrainie lewica postkomunistyczna Die Linke: „obarczyła rząd federalny częściową odpowiedzialnością za eskalację napięcia na Ukrainie, jednocześnie protestując przeciwko oskarżaniu strony rosyjskiej za eskalowanie napięcia" (Kubiak, 2014, s. 309).

Jeszcze bardziej emocjonalnie temat ukraiński zaakcentowano podczas wiecu wyborczego SPD zorganizowanego na placu Aleksandra w Berlinie, na sześć dni przed ogłoszeniem wyników wyborów do Europarlamentu. Wtedy to minister spraw zagranicznych z ramienia SPD Frank-Walter Steinmeier, znany ze spokojnego usposobienia i temperamentu sprowokowany został przez zwolenników polityki rosyjskiej na Ukrainie. W ostrym przemówieniu skrytykował niemieckich zwolenników polityki prorosyjskiej i zagroził sankcjami wobec Rosji w przypadku, kiedy separatyści rosyjscy będą próbowali zakłócić wybory prezydenckie na Ukrainie(PAP, polskieradio.pl, 2014).

W prasie polskiej oceniono również stopień zaangażowania społeczeństwa niemieckiego w Eurowybory. Wśród analityków i publicystów przeważały opinie że frekwencja w Niemczech - podobnie jak w innych państwach UE - będzie niższa niż dotychczas oraz że „Niemcy są zmęczeni »Europą«. Poirytowani dysfunkcjonalnością Unii w wielu obszarach i zaowocuje to niska frekwencją wyborczą" (Księżniakiewicz, 2014, s. 5). Jak się okazało w wyborach do Parlamentu Europejskiego w Niemczech w 2014 roku frekwencja wyniosła 48,1\% głosów, i był to wynik o ponad 4\% lepszy od udziału niemieckiego elektoratu w poprzednich Eurowyborach z 2009 roku. Zważywszy na słabnące zainteresowanie wyborami do Parlamentu Europejskiego w Europie z całą pewnością wynik ten należy uznać za zadowalający.

W opinii Aleksandry Radziwoń z Centrum Inicjatyw Międzynarodowych na pewno pozytywnie na frekwencję w Niemczech wpłynął fakt, iż w 10 krajach związkowych w tym samym dniu odbywały się wybory lokalne, które zazwyczaj bardziej motywują wyborców do pójścia do lokali wyborczych (Radziwoń, 2015). Obecnie poparcie dla wyborów europejskich w RFN jest na stałym poziomie i sięga około 43-45\%. Przewyższa nieznacznie średnią europejską. Pomimo tego od dłuższego czasu w Niemczech zauważalna jest prawidłowość, że wybory do Bundestagu lub krajowe cieszą się zdecydowanie większym zainteresowaniem społeczeństwa niż wybory do Parlamentu Europejskiego. Wynika to głównie z tego, że niemieckie społeczeństwo nie odczuwa przełożenia wyników wyborów czy też decyzji podejmowanych przez Europarlament na skład 
krajowego rządu i parlamentu, nie wspominając o ich codziennym życiu. Nie dziwi więc fakt, że w tej kampanii wyborczej do PE sprawy krajowe wypierały problemy europejskie, a prasa niemiecka sugerowała, że Eurowybory stanowią ewentualnie ,poligon doświadczalny”, gdzie partie sondują różne możliwości przed wyborami krajowymi.

Mniejsze zainteresowanie społeczeństwa niemieckiego Eurowyborami, aniżeli wyborami krajowymi, dobitnie potwierdza również porównanie dwóch debat politycznych transmitowanych w telewizji niemieckiej w trakcie trwających kampanii wyborczych do Bundestagu w 2013 roku oraz do Europarlamentu w 2014 roku. Polityczną debatę o fotel kanclerza pomiędzy Angelą Merkel a Peerem Steinbrückiem obejrzało 17,7 milionów ludzi. Drugą debatę, która odbyła się w trakcie kampanii do Europarlmentu pomiędzy Jeanem Claudem Junckerem a Martinem Schulzem - przedstawicielami największych frakcji w Europarlamencie chadecji oraz socjaldemokracji obejrzało jedynie 1,8 miliona Niemców (około 6\% telewidzów). Prasa polska, powołując się na niemieckie media odnotowała, że „w ocenie widzów w czasie pojedynku bardziej przekonujący był Steinbrück, natomiast za lepszego kanclerza większość uważa Merkel" (Dudek, 2014).

Istotnym czynnikiem determinującym perspektywę oceny wyników Eurowyborów w Niemczech była decyzja podjęta przez Federalny Trybunał Konstytucyjny w RFN, który zrezygnował z tzw. klauzuli zaporowej, która w poprzednich Eurowyborach z 2009 roku wyniosła 5\%. W grudniu 2011 roku Federalny Trybunał Konstytucyjny uznał ją za niezgodną z Ustawą Zasadniczą. W związku z powyższym, w październiku 2013 roku w Bundestagu przegłosowano decyzję o obniżeniu progu wyborczego do 3\%. Jednak tą ustawę zaskarżyły do Trybunału Konstytucyjnego partie mniejsze, które przy utrzymaniu wspomnianej klauzuli miałyby niewielkie szanse na uzyskanie przepustek do PE. Ostatecznie, sąd konstytucyjny RFN przyznał rację partiom mniejszym. Jak zauważa Michał Kosman, dzięki temu ,aż siedem ugrupowań skorzystało na tej modyfikacji uzyskując po jednym mandacie. Łącznie aż czternaście partii niemieckich znalazło się w Parlamencie Europejskim(Kosman, 2014, s. 286). W polskiej publicystyce zwrócono uwagę, że dzięki decyzji Trybunału Konstytucyjnego nawet reprezentanci partii ekstremistycznych takich jak NPD otrzymali przepustkę do Strasburga (PAP, 2014). Zmiana ta uratowała też polityczny byt FDP, która jak już wcześniej wspomniano odnotowała w wyborach europejskich z 2014 roku wynik gorszy niż przed pięcioma laty aż o 7,6\% głosów. 
W wyborach do Parlamentu Europejskiego w RFN w 2014 roku zwyciężyła koalicja CDU-CSU, która zdobyła 35,36\% głosów. Prasa niemiecka podkreślała, że choć sam wynik osiagnięty przez chadeków na pewno cieszy ich sympatyków to jednak był to najgorszy rezultat, jaki CDU osiagnęła od 1979 roku, czyli od pierwszych wyborów do Parlamentu Europejskiego, które odbyły się w państwach EWG. Zdaniem publicystów prasy polskiej i niemieckiej spadek notowań chadeków był głównie spowodowany słabymi wynikami CSU, która straciła osiem punktów procentowych w Bawarii (www.niemcyonline, 2014). W opinii wspomnianej już Aleksandry Radziwoń spadek poparcia dla koalicji, głównie za sprawą CSU spowodowany był ,nie tylko wprowadzeniem atrakcyjniejszego pakietu socjalnego dla osób w kategorii wiekowej 60 plus, ale samą postawą sekretarza generalnego CSU, Andreasa Scheuera, który podkreślając swój sceptycyzm wobec UE próbował wykreować CSU na atrakcyjniejszą alternatywę wobec partii AfD oraz Freie Wähler"'(Radziwoń, 2014).

Relatywnie słabsze notowania koalicji w porównaniu do lat poprzednich bynajmniej nie zmniejszyły wysokiego poziomu zadowolenia wyrażanego przez liderów partii: „CDU wniosło swoją cegiełkę do tego, by Europejska Partia Ludowa znowu stała się najsilniejszą partią w Strasburgu, a na czele KE mógł stanąć Jean-Claude Juncker" (Stasik, 2014), podsumował czołowy niemiecki kandydat CDU, były premier Dolnej Saksonii David McAllister. W porównaniu do 2009 roku koalicja ta osiąnęła więc wynik o 2,6\% głosów gorszy niż w poprzednich Eurowyborach. Jednak i tak, ostatecznie przyczyniła się do zwycięstwa Europejskiej Partii Ludowej w Eurowyborach z 2014 roku.

Drugie miejsce w wyborach do Parlamentu Europejskiego w Niemczech zajęła SPD z poparciem sięgającym 27,27\% głosów. Partia odnotowała tym samym $6,5 \%$ większe poparcie niż przed pięcioma laty. $\mathrm{Na}$ łamach publicystyki polskiej sugerowano, że czołowi przywódcy SPD z Sigmarem Gabrielem na czele jednoznacznie wskazali na Martina Schultza, którego uznali twarzą kampanii partii, lokomotywą wyborczą oraz źródłem sukcesów Socjaldemokratów (Kędzierski, 2014).

Z kolei Tomasz Mysłek na łamach „Gazety Polskiej” powołał się na analizy i komentarze polskich politologów, z których wynikało, że kandydat SPD mógł również liczyć na wsparcie Sojuszu Lewicy Demokratycznej w Polsce oraz kilku innych europejskich partii postkomunistycznych. Publicysta prawicowego tygodnika przyznał również, że Schultz był także najjaśniejszą postacią swojego ugrupowania. Nadmienił również, że w kampanii wyborczej lider niemieckiej socjaldemokracji wy- 
raźnie akcentował, że chce usunąć wszelkie symbole religijne przestrzeni publicznej (Mysłek, 2014).

Zgodnie z przewidywaniami, kolejne miejsce w sondażach zajęły: partia Zielonych z wynikiem 10,71\% głosów oraz postkomunistyczna lewica, która osiagnęła poparcie sięgające 7,39\% głosów. Wprawdzie obie partie uzyskały relatywnie gorszy rezultat w porównaniu do poprzednich Eurowyborów z 2009 roku, to jednak wynik przełożył się na liczbę mandatów w nowym Parlamencie Europejskim; w przypadku Zielonych było to 11 mandatów, a w przypadku Die Linke -7 mandatów.

Zaskakująco wysoki wynik w niemieckich Eurowyborach osiągnęła eurosceptyczna partia Alternatywa dla Niemiec, która zdobyła 7,03\% głosów poparcia i to zdominowało polskie komentarze o niemieckich eurowyborach. Warto przypomnieć, że ugrupowanie to powołane zostało w lutym 2013 roku i wystartowało w jesiennych wyborach do Bundestagu, gdzie osiagnęło poparcie sięgające 4,7\% głosów. W prasie polskiej szeroko komentowano sukces eurosceptycznego ugrupowania i jeszcze przed ogłoszeniem wyników Eurowyborów w RFN zapowiadano sukces AFD. W tygodniku „Najwyższy Czas” Olgierd Domino ocenił, że sukces Alternatywy jest przesądzony, gdyż „tzw. Partia profesorów sprzeciwia się europejskiej uniformizacji [...] żądają mniej Europy, a więcej wolności" (Domino, 2014). Na łamach artykułu Prawica wyzwoli Europe publicysta tygodnika zacytował również jednego z członków eurosceptycznej partii, który stwierdził, że „O długości i krzywiźnie ogórków chcemy decydować w Berlinie, a nie w Brukseli” (Domino, 2014).

Prasa polska źródeł sukcesu AFD upatrywała także w zmianie - transformacji, jakiej uległy ugrupowania liberalne w Niemczech. Powołując się na dziennik „Tageszeitung” publicyści polscy zwrócili uwagę, że „W Niemczech zaliczają się do nich ci - którzy zarabiają więcej od innych, są zmęczeni multikulturową republiką i nie mają zamiaru spłacać długów Grecji” (www.voxeurop.eu.pl, 2014).

W podobnym tonie na łamach „Polityki” wypowiedział się znany komentator spraw międzynarodowych Wawrzyniec Smoczyński. W artykule zatytułowanym Europopuliści wszystkich krajów łaczcie się ocenił wyniki wyborów w Niemczech i zasugerował, że ,Angela Merkel z Alternatywą dla Niemiec pod bokiem nie zgodzi się na umorzenie długów Grecji” (Smoczyński, 2014).

Z kolei w tygodniku „W Sieci” zamieszczono rozmowę Sławomira Sieradzkiego z Hansem Olafem-Henkelem jednym z przywódców AFD. W rozmowie prezes partii zwrócił uwagę, że AFD jest postrze- 
gana jako partia kontrowersyjna w RFN i dlatego jest kontestowana przez tamtejsze media. Według prezesa partii - Hansa Olafa-Henkela, wynikało to głównie z programu proponowanego wyborcom, w którym postulowano powrót do marki niemieckiej w RFN oraz sprzeciwiano się federalizacji europejskiej. Jak zauważył lider ugrupowania „partia silnie wspiera tradycyjne wartości, co wywołuje agresję lewicowych środowisk. Padają wobec niej oskarżenia o prawicowy ekstremizm" (Sieradzki, 2014). Po Eurowyborach partia zasiliła w Parlamencie Europejskim Frakcję Europejskich Konserwatystów i Reformatorów, choć jak podkreślali liderzy jej ugrupowania nie wykluczała współpracy z innymi frakcjami.

Olga Doleśniak-Harczuk na łamach „Gazety Polskiej” w artykule Buntownicy u brukselskich bram, z podziwem odnotowała, że Alternatywa dla Niemiec nie tylko nie podzieliła losu krótkodystansowców z Die Freiheit, ale „wykosiła liberałów z FDP” (Doleśniak-Harczuk, 2014). Publicystka podkreśliła, że w programie wyborczym ugrupowanie otwarcie deklarowało niechęć do zawiązania unijno-amerykańskiej strefy wolnego handlu. W związku z powyższym zapowiadała, że po wyborach, w Parlamencie Europejskim Alternatywa będzie współpracowała nie tylko z francuskim Frontem Narodowym Marine le Pen, ale również z Zielonymi i jej austriacką liderką Urlike Lunacek na czele, która zażądała od Rady Europy ujawnienia dokumentów negocjacyjnych ws. Umowy o wolnym handlu UE z USA (Doleśniak-Harczuk, 2014).

Kilka dni po ogłoszeniu wyników Eurowyborów w Niemczech, Tomasz Mysłek na łamach wspomnianego już tygodnika „Najwyższy Czas” w artykule Ostrzeżenia i niepokoje ocenił przebieg kampanii wyborczej do PE w RFN i podkreślił, że dzięki obecności AFD na scenie politycznej Niemiec była ona barwna i różnorodna: „nie było już - jak dawniej - niemal samych monotonnych i nudnych dyskusji między różnymi spasionymi socjalistami i lewakami, a na ogół oportunistyczno-socjaldemokratycznymi tzw. chadekami z CDU i CSU czy demo liberałami z FDP" (Mysłek, 2014). Publicysta tygodnika podkreślił, że jej wolnościowy program prowokował szczególnie neokomunistycznych lewaków w Niemczech, którzy podczas kampanii wyborczej kilkukrotnie przypuścili atak na wolnościową prawicę. Nawiązał tym samym do relacji tygodnika „Frankfurter Allgemaine Zeitung”, który odnotował chuligańskie wybryki około 250 osób na wiecu wyborczym AFD we Frankfurcie. Próbowali oni zakłócić spokojny wiec wyborczy Alternatywy i obrzucili jej liderów pojemnikami z farbą i jajkami (Mysłek, 2014). 
W prasie polskiej oceniono, że zaskakujący sukces AfD raczej nie wzmocni eurofobicznych tendencji w Niemczech. Francuski politolog Dominique Moisi w rozmowie z Maciejem Nowickim na łamach „Newsweeka” zasugerował, że z jednej strony sytuacja ta wynika z powodów historycznych - pokuty za II wojnę światową. Z drugiej, większość niemieckiego społeczeństwa jest zadowolone ze swojej sytuacji gospodarczej (Nowicki, 2014). W innych publikacjach prasowych sugerowano, że sukces Alternatywy to „naturalny wyraz opinii części mniejszościowej niemieckiego społeczeństwa, które dotychczas nie było w żaden sposób reprezentowane na szczeblu europejskim" (www.euroactiv.pl, 2014).

Publicyści polscy większe zagrożenie upatrywali w wejściu do Europarlamentu neofaszystowskiego członka partii NPD, niż w realizacji programu Alternatywy. Jacek Pawlicki na łamach „Newsweeka” w artykule Siostry i bracia Korwina zwrócił uwagę, że rodowód, poglądy i prowokacyjnego lidera - Udo Voighta napawać mogą strachem entuzjastów pogłębienia procesu integracji europejskiej. Przywódca NPD stwierdził bowiem, że np. Adolf Hitler jest wielkim niemieckim mężem stanu i zażądał, aby „hajlowanie” - gest nazistowski był zalegalizowany, gdyż jest pozdrowieniem pokojowym. Postulował również, aby pośmiertnie przyznać Rudolfowi Hessowi - zastępcy Adolfa Hitlera pokojową Nagrodę Nobla (Pawlicki, 2014).

Tak jak Alternatywę okrzyknięto największą rewelacją niemieckich Eurowyborów, tak FDP ogłoszono największą porażką majowych wyborów europejskich w RFN. Liberałowie zdobyli tylko 3,4\% głosów, i był to rezultat gorszy o 7,6\% od ostatnich Eurowyborów. Jak zauważył Piotr Madajczyk FDP pogrążona jest w kryzysie już od 2010 roku. Od tego czasu współpraca koalicji nie układała się tak dobrze jak podczas jej tworzenia. „Często dochodziło do sporów FDP-CSU. [...] Kolejne tytuły w gazetach informowały o buncie w partii, atakach na jej przewodniczącego, że jest on obciążeniem, a nie wsparciem w wyborach odbywających się w krajach związkowych" (Madajczyk, 2012, s. 99).

Wyniki kolejnych siedmiu partii niemieckiej sceny politycznej: Die Partei, FW, Tierschutzpartei, NPD, Familie, ODP, Partia Piratów przełożyły się na uzyskanie przez nie po jednym mandacie w Europarlamencie. W Polsce odnotowano to jako swoistą ciekawostkę, będącą rezultatem zniesienia 5\% progu wyborczego. Ugrupowania te w większości zasiliły partie eurosceptyczne i eurorealistyczne.

Po zakończonych w Polsce i w Niemczech wyborach do Parlamentu Europejskiego (2014) prasa polska zwracała uwagę, że w obu krajach 
zwyciężyły partie aktualnie znajdujące się u władzy. Jednocześnie oba ugrupowania odnotowały też relatywny spadek zaufania wyborców. $\mathrm{O}$ ile w Polsce przewagę PO nad PiS-em można uznać za zwycięski remis, o tyle różnica pomiędzy CDU/SCU a socjaldemokratami była dość wyraźna, gdyż sięgnęła około 8\% głosów. Publicyści polscy zwracali uwagę, że podobnie w obu krajach zwyciężyły partie wspierające proeuropejski kierunek działań UE i należące do frakcji Europejskiej Partii Ludowej.

W publicystyce polskiej z dużą uwagą śledzono przebieg kryzysu politycznego na Ukrainie. W prasie zwracano uwagę, że tzw. kryzys ukraiński był obecny w kampanii wyborczej czołowych partii politycznych zarówno w Polsce, jak i w RFN. Odnotowano również, że w Niemczech był źródłem podziałów nie tylko między partiami politycznymi, ale również społeczeństwem.

Wobec coraz mniejszego, ogólnego zainteresowania Europejczyków wyborami do Parlamentu Europejskiego, poziom frekwencji wyborczej w RFN można uznać za satysfakcjonujący. Był wyższy aniżeli w 2009 roku i mieścił się powyżej średniej europejskiej. Tego na pewno nie można powiedzieć o Polsce. Publicyści polscy zwracali uwagę, że niewielki wzrost zainteresowania Eurowyborami w 2014 roku w porównaniu do Eurowyborów poprzednich nie zmienił negatywnej opinii o Polakach jako o narodzie niedojrzałym do demokracji i niechętnym do zinstytucjonalizowanych form aktywności obywatelskiej, a w szczególności do wyborów europejskich.

Prasa polska zwracała uwagę, że zarówno w Polsce, jak i w Niemczech utrwaliły się też niektóre trendy po ostatnich wyborach krajowych. W Polsce, od ostatnich wyborów lokalnych oraz europejskich zdecydowanie wzrosło poparcie dla największej partii opozycyjnej - PiS, kosztem partii rządzącej - PO. Tymczasem w Niemczech wyniki Eurowyborów utrwaliły tendencję utrzymującą się po jesiennych wyborach do Bundestagu polegającą na spadku notowań liberałów z FDP, a wzroście poparcia społeczeństwa dla eurosceptycznej Alternatywy dla Niemiec.

W polskiej publicystyce podkreślono, że pomimo tego, iż w kampanii do Europarlamentu w obu państwach nie zabrakło haseł europejskich, to zarówno społeczeństwo polskie, jak i niemieckie wykazywało zdecydowanie większą wrażliwość na problemy krajowe aniżeli wspólnotowe. Utrwaliła się więc podobna tendencja w Polsce i Niemczech: wypierania problematyki europejskiej w kampanii wyborczej na korzyść haseł dotyczących spraw krajowych. 
Prasa polska szeroko komentowała sukces partii eurosceptycznych w Polsce i w Niemczech. W obu krajach zaskakująco dobre wyniki osiągnęły ugrupowania kontestujące główny nurt Unii Europejskiej zakreślony po pojawieniu się kryzysu w strefie euro: Kongres Prawicy Polskiej oraz Alternatywa dla Niemiec. Sukces eurosceptycznych ugrupowań był wyróżniającą cechą wyborów do Parlamentu Europejskiego z 2014 roku w zarówno Polsce, jak i w Niemczech, a też w większości państw Unii Europejskiej.

\section{Bibliografia}

Baranowska K. (2014), Choroba wieku młodzieńczego, „Do Rzeczy”, 5-11 maja. Bielecki T. (2014), Po co nam Parlament Europejski, „Gazeta Wyborcza”, 19 maja. Bielecki T., Grochal R., Kondzińska A. (2014), Nasz euroranking, „Gazeta Wyborcza”, 21 maja.

Doleśniak-Harczuk O. (2014), Buntownicy u brukselskich bram, „Gazeta Polska”, 28 maja.

Domino O. (2014), Prawica wyzwoli Europe, „Najwyższy Czas”, 24 maja.

Dudek B. (2013), Debata Merkel-Steinbrück w TV. Widzowie wydali wyrok, http:// www.dw.com/pl/debata-merkel-steinbr\%C3\%BCck-w-tv-widzowie-wydaliwyrok/a-17059203, 20.06.2014.

Grochal R. (2014), Tusk walczy o wyborce 55+, „Gazeta Wyborcza”, 14 maja.

Gursztyn P. (2014a), Dziwni kandydaci, „Do Rzeczy”, 22-27 kwietnia.

Gursztyn P. (2014b), Polski euromajdan, „Do Rzeczy”, 31 marca-6 kwietnia.

Kędzierki M. (2014), Niemcy po euro wyborach - (prawie sami zwycięzcy), http:// www.psz.pl/120-unia-europejska/niemcy-po-eurowyborach-prawie-samizwyciezcy, 29.11.2014.

Kosman M. (2014), Programy niemieckich partii politycznych w wyborach do Parlamentu Europejskiego w 2014 roku. Wybrane aspekty, ,Rocznik Integracji Europejskiej", nr 8.

Księżniakiewicz M. (2014), Niemieckie wybory do parlamentu Europejskiego. „, Masz dziadka, wyślij go do Europy”, „Biuletyn Niemiecki”, nr 48, 30.06.2014.

Kubiak P. (2014), Wybory do Parlamentu Europejskiego w Niemczech (25.05.2014). Analiza i nastepstwa, „Rocznik Integracji Europejskiej”, nr 8.

Lichocka J. (2014), Ostatni taki wynik PO, „Gazeta Polska”, 28 maja.

Lipiński Z. (2014), Korwin Górq, Palikot na dnie!, „Myśl Polska”, 8-15 czerwca.

Madajczyk P. (2012), Kryzys w FdP czy kryzys liberalizmu w Niemczech, „Myśl ekonomiczna i polityczna", $\mathrm{nr} 1$.

Majewski P. (2014), Wyborczy nie widzq kampanii, „Rzeczpospolita”, 25 kwietnia. 
Makowski J. (2014), Fruwajacy elektorat buntu, „Gazeta Wyborcza”, 16 maja.

Marczuk B. (2014), Rozmowa z J. Flisem, „Rzeczy Wspólne”, nr 2.

Mysłek T. (2014), Ostrzeżenia i niepokoje, „Najwyższy Czas”, 31 maja.

Nowicka K. (2014), Pudelek Europejski, „Wprost”, 30 marca;

Nowicki M. (2014), Europa sięgnęła dna, „Newsweek”, 26.05-1.06.

PAP (2014), Tak Europa głosowała w wyborach do Parlamentu Europejskiego, http:// wiadomosci.dziennik.pl/polityka/artykuly/460044,tak-europa-glosowala-wwyborach-do-parlamentu-europejskiego.html, 29.01.2016.

PAP (2014), polskieradio.pl (29.06.2016).

www.niemcyonline (2014) (29.06.2016).

www.voxeurop.eu.pl (2014) (29.06.2016).

\section{Polish press coverage of the $\mathbf{2 0 1 4}$ elections to the European Parliament in Poland and Germany}

\section{Summary}

The main objective of this paper is to present the opinions of Polish press journalists about the results of the elections to the European Parliaments held in Poland and Germany in 2014. It stresses the methods applied in the election campaigns by Polish and German political parties and the foci of election platforms of parties in either country. The main winners and losers of the 2014 elections to the European Parliament are also presented.

Key words: European integration, European Parliament, Euroskepticism, elections to the European Parliament, election campaign, Polish press 